\title{
CONCEPTUAL BASIS OF TAX POLICY FORMATION IN THE GLOBALIZATION CONDITIONS
}

\author{
Svitlana Khalatur ${ }^{1}$, Olena Trokhymets ${ }^{2}$, Oleksandr Karamushka ${ }^{3}$
}

\begin{abstract}
The purpose of the article is to analyze the tax systems of the countries of the European Union and Ukraine, the impact of individual indicators of the tax system on the economies development, study the possibility of applying the accumulated experience. The subject-matter of the study is the methodological and conceptual foundations of the tax policy-making process of the EU and Ukraine. Methodology. Based on the analyzed scientific literature on tax policy formulation of countries, the methodological principles of this study provide for the joint application of a set of well-known general scientific and special methods of research in economics. In particular, the dialectical method, the method of scientific abstraction, the method of systematic analysis, economic and mathematical modeling were used. Results. The article analyzes the individual indicators of the tax system functioning of 28 countries of the European Union and Ukraine; and the impact of these indicators on the economy development. In particular, the following indicators were studied: customs and other import duties, firms expected to give gifts in meetings with tax officials; firms that do not report all sales for tax purposes; firms visited or required meetings with tax officials; labor tax and contributions; net taxes on products; other taxes; other taxes payable by businesses; profit tax; tax payments; tax revenue; taxes on exports; taxes on goods and services; taxes on income, profits and capital gains; taxes on income, profits and capital gains; taxes on international trade; time to prepare and pay taxes; total tax rate. The dependence of foreign direct investment on profit tax, tax revenue; taxes on income, profits and capital gains; time to prepare and pay taxes and total tax rate have been studied. The study shows that, on average, tax revenue affects foreign direct investment, net inflows with the same strength as time to prepare and pay taxes, but almost twice as much as taxes on income, profits and capital gains. Practical implications. The article contains a set of tools and rules for reviewing approaches, guidelines and criteria for the effectiveness of Ukraine's tax policy in line with the global development concept. Value / originality. The conceptual criteria for the formation and implementation of the tax policy of the state are determined, it is carried out the comparative analysis of the tax policy of Ukraine and the EU countries within the framework of the European economic integration, which occurs simultaneously with the globalization of the world economy.
\end{abstract}

Key words: tax, labor tax, tax rate, profit tax, tax revenue.

JEL Classification: C51, E62, F63

\section{Introduction}

Being a coherent system, the economic system of a country combines the various, often conflicting interests of its members. At the same time, the process of tax regulation is also free of conflicts, since the interests and local goals of its participants do not coincide.
Exacerbation of conflicts arising in the process of tax policy development of the state occurs during periods of downturn, increased competition and in times of economic crisis. This fact necessitates the search for the concept of the tax policy of the state aimed at the maximum reduction of conflict situations in order to

\footnotetext{
Corresponding author:

${ }^{1}$ Dnipro State Agrarian and Economic University, Ukraine.

E-mail: skhalatur@gmail.com

ORCID: https://orcid.org/0000-0001-8331-3341

ResearcherID: T-7645-2019

${ }^{2}$ Classic Private University, Ukraine.

E-mail: yelena.trohim@gmail.com

ORCID: https://orcid.org/0000-0001-7587-7948

ResearcherID: O-2591-2018

${ }^{3}$ Dnipro State Agrarian and Economic University, Ukraine.

E-mail: k80504949768@gmail.com

ORCID: https://orcid.org/0000-0002-9369-7972

ResearcherID: T-7645-2019
} 
preserve the stability and integrity of society, reduce social tension.

European economic integration, which occurs at the same time as the globalization of the world economy, updates tax policy studies not only at the level of the state, which, in particular, seeks to reap the benefits of engaging in global economic ties and participation in integration processes, but also at the level of integration (supranational level). Moreover, these two tax policy makers develop it to achieve positive shifts in socio-economic development, but set different goals depending on their priorities for functioning and development. A taxpayer state aims primarily to pursue its own national interests under specific internal and external socio-economic and institutional conditions (including, depending on whether it seeks to improve the functioning of its economy as one of the world leaders in terms of economic development), is geared to growing economic development by reducing the gap between world leaders). At the same time, the tax policy of integration education presupposes balancing of often conflicting national interests in order to create favorable conditions for the development of integration education as a whole and its participants in particular. Sometimes this requires the latter's consent to the deterioration of certain economic conditions for other benefits in the near future as well as in the future.

The aim of the article is to analyze the tax systems of the countries of the European Union and Ukraine, the impact of individual indicators of the tax system on the economies development, to study the possibility of applying the learned lessons.

\section{Previous research review}

Naidenko O. (2019) writes that the socio-economic processes that take place in the country affect the welfare of the population. Rating estimates of recent years indicate deterioration in the level of well-being, human and social development of the population in Ukraine, global wealth.

Hrysenko M., Pryiatelchuk O. and Shvorak L. (2019) argue that the social market economy is the dominant economic system for industrialized countries. In addition to creating economic and technological conditions, the active participation of the state is a key factor in the effective functioning and sustainable development of the economy. Glushchenko J. and Kozhalina N. (2019) consider local taxation, its problematic aspects and trends. Economic independence of any community is not possible without sufficient financial resources, relative independence of tax and other mandatory payments.

Uwuigbe O. R., Omoyiola A., Uwuigbe U., Lanre N. and Ajetunmobi O. (2019) write that taxation is a very important tool in any country. It is a macroeconomic tool, very necessary for the functioning of the state. Oladipo O. A., Iyoha F., Fakile A., Asaleye A.J. and
Eluyela D. F. (2019) rightly argue that taxation is a sustainable and genuine source of government revenue, a tool for macroeconomic policy and fiscal management.

\section{Modern trends in tax policies of Ukraine and the European countries}

Conceptual criteria for the formation and implementation of state tax policy are the following:

1. Compromise. It is necessary to balance the interests of the state, business sector and citizens, so that all subjects of redistribution relations are satisfied with the results of redistribution approximately equally. Government expenditures should ensure the optimal combination of social measures and measures to promote GDP growth.

2. Complementarity of tax changes. Tax innovations should be well coordinated with other legislation, provide for measures to influence the informal level of the institutional environment, and be positively assessed by society.

3. Rejection of radical tax initiatives. Significant changes in taxation are often associated not so much with the positive economic effect and expansion of the tax base, but with the fiscal losses that have to be offset by government borrowing.

4. Stability and flexibility. The tax policy should, on the one hand, correspond to the directions of modification of the tax system and the system of contributions to state social funds defined in its concept, and on the other hand, to respond to changes in the reproductive and fiscal processes quickly.

For a more detailed explanation of the study topic, let us analyze the individual indicators of the tax system functioning of 28 countries of the European Union and Ukraine; and the impact of these indicators on the economy development. Thus, let us compare the indicators related to the tax system in the EU countries and Ukraine, in particular the following indicators will be analyzed: customs and other import duties (\% of tax revenue); firms expected to give gifts in meetings with tax officials (\% of firms); firms that do not report all sales for tax purposes (\% of firms); firms visited or required meetings with tax officials (\% of firms); labor tax and contributions (\% of commercial profits); net taxes on products (current US\$); other taxes (\% of revenue); other taxes payable by businesses (\% of commercial profits); profit tax (\% of commercial profits); tax payments (number); tax revenue (\% of GDP); taxes on exports ( $\%$ of tax revenue); taxes on goods and services (\% of revenue); taxes on goods and services (\% value added of industry and services); taxes on income, profits and capital gains (\% of revenue); taxes on income, profits and capital gains (\% of total taxes); taxes on international trade ( $\%$ of revenue); time to prepare and pay taxes (hours); total tax rate (\% of commercial profits). 
Vol. 6, No. 2, 2020

Baltic Journal of Economic Studies

Table 1

The average value of the tax system functioning of the EU and Ukraine for the period of 2001-2019

\begin{tabular}{|c|c|c|c|c|c|c|}
\hline Country Name & $\begin{array}{c}\text { Labor tax and } \\
\text { contributions (\% of } \\
\text { commercial profits) }\end{array}$ & $\begin{array}{c}\text { Other taxes } \\
\text { (\% of revenue) }\end{array}$ & $\begin{array}{c}\text { Profit tax } \\
\text { (\% of commercial } \\
\text { profits) }\end{array}$ & $\begin{array}{c}\text { Tax payments } \\
\text { (number) }\end{array}$ & $\begin{array}{l}\text { Tax revenue } \\
\text { (\% of GDP) }\end{array}$ & $\begin{array}{c}\text { Taxes on goods } \\
\text { and services } \\
\text { (\% of revenue) }\end{array}$ \\
\hline Austria & 34.41 & 3.93 & 16.86 & 12.00 & 26.01 & 27.18 \\
\hline Belgium & 48.55 & 0.50 & 8.50 & 11.00 & 25.02 & 25.08 \\
\hline Bulgaria & 23.24 & 0.16 & 5.19 & 16.33 & 19.67 & 44.42 \\
\hline Croatia & 19.11 & 0.74 & 0.00 & 24.93 & 20.73 & 46.25 \\
\hline Cyprus & 12.37 & 4.85 & 8.78 & 27.83 & 31.57 & 35.02 \\
\hline The Czech Republic & 38.77 & 0.14 & 5.60 & 10.60 & 14.44 & 28.50 \\
\hline Denmark & 3.11 & 4.56 & 20.84 & 10.00 & 32.84 & 37.84 \\
\hline Estonia & 38.79 & -8.58 & 7.67 & 20.14 & 36.24 & \\
\hline Finland & 26.09 & 0.79 & 14.65 & 11.20 & 20.82 & 36.38 \\
\hline France & 51.82 & 4.26 & 4.37 & 11.40 & 22.63 & 23.36 \\
\hline Germany & 21.68 & -22.06 & 10.40 & 11.22 & 23.37 & \\
\hline Greece & 30.58 & 2.99 & 17.54 & 10.20 & 22.21 & 31.39 \\
\hline Hungary & 35.47 & 1.09 & 10.17 & 12.33 & 21.89 & 35.97 \\
\hline Ireland & 12.13 & 2.01 & 12.15 & 9.00 & 22.64 & 34.41 \\
\hline Italy & 41.52 & 5.01 & 23.06 & 13.80 & 22.35 & 22.79 \\
\hline Latvia & 27.05 & 0.47 & 6.27 & 8.47 & 21.24 & 41.00 \\
\hline Lithuania & 35.17 & 0.24 & 6.47 & 11.07 & 17.87 & 34.07 \\
\hline Luxembourg & 15.44 & 2.09 & 4.32 & 23.00 & 25.02 & 30.45 \\
\hline Malta & 10.84 & 0.57 & 31.16 & 7.44 & 38.43 & 35.45 \\
\hline Norway & 15.90 & 0.51 & 23.91 & 4.13 & 25.94 & 25.16 \\
\hline Poland & 25.15 & 0.73 & 15.05 & 23.80 & 16.49 & 35.82 \\
\hline Romania & 29.81 & 0.17 & 11.61 & 62.67 & 17.21 & 36.26 \\
\hline The Slovak Republic & 39.65 & 0.06 & 8.38 & 22.20 & 16.62 & 30.10 \\
\hline Slovenia & 19.41 & 1.79 & 13.74 & 15.33 & 19.22 & 35.36 \\
\hline Spain & 35.55 & 0.19 & 15.75 & 8.80 & 14.25 & 43.37 \\
\hline Sweden & 35.81 & 29.75 & 15.07 & 6.00 & 27.05 & 37.26 \\
\hline Ukraine & 40.57 & -0.01 & 11.17 & 72.73 & 16.96 & 32.98 \\
\hline The United Kingdom & 11.16 & 5.38 & 20.71 & 8.07 & 25.12 & 32.34 \\
\hline
\end{tabular}

Source: compiled by authors based on World Bank data

Having analyzed Table 1, we can draw the following conclusions. Labor tax and contributions is highest in France (51.82\% of commercial profits), in Belgium (48.55\% of commercial profits), in Italy (41.52\% of commercial profits); and the lowest one is in Denmark (3.11\% of commercial profits), in Malta (10.84\% of commercial profits), in the United Kingdom (11.16\% of commercial profits). In Ukraine, this figure is at $40.57 \%$ of commercial profits. In terms of other taxes payable by businesses (\% of commercial profits), it can be said that the highest level is in France $(10.49 \%)$, the lowest one is in Norway $(0.03 \%)$, and in Ukraine it is $0.91 \%$.

Tax revenue refers to compulsory transfers to central government for public purposes. Tax revenue in $\%$ of GDP is the lowest in Germany (11.22\%), the highest one is in Malta (38.43\%), and in Ukraine it averages to $16.96 \%$. Taxes on goods and services include general sales and turnover or value added taxes, selective excise taxes on goods, selective taxes on services, taxes on the use of goods or property, and some others. Taxes on goods and services in $\%$ of revenue is highest in Croatia
(46.25\%), lowest one is in Italy (22.79\%); in Ukraine this indicator is at the level of $32.98 \%$.

The continuation of the analysis of the tax system functioning indicators of the EU and Ukraine is shown in Table 2.

After analyzing such indicators: customs and other import duties (\% of tax revenue), firms expected to give gifts in tax officials meetings ( $\%$ of firms), firms that do not report all sales for tax purposes (\% of firms), firms visited or required meetings with tax officials (\% of firms), it can be said that in many studied countries this data is missing. In Ukraine, they are at 6.43; 46.65; $31.90 ; 59.15$ respectively. The highest value of the first indicator was recorded in Slovenia (2.22); the lowest one was in Greece (0.02). The second indicator, firms expected to give gifts in meetings with tax officials (\% of firms) ranges from 28.80 in Greece to 0.30 in Sweden. Firms that do not report all sales for tax purposes (\% of firms) range from 53.19 in Greece to 18.33 in Spain. Firms visited or required meetings with tax officials (\% of firms): the highest one was in Bulgaria (64.77) and the lowest one was in Sweden (8.90). 
Table 2

The average value of the tax system functioning of the EU and Ukraine for the period 2001-2019

\begin{tabular}{|c|c|c|c|c|c|c|}
\hline Country Name & $\begin{array}{c}\text { Taxes on income, } \\
\text { profits and capital } \\
\text { gains } \\
(\% \text { of revenue })\end{array}$ & $\begin{array}{c}\text { Taxes on income, } \\
\text { profits and capital } \\
\text { gains } \\
\text { (\% of total taxes) }\end{array}$ & $\begin{array}{c}\text { Taxes on } \\
\text { international } \\
\text { trade } \\
\text { (\% of revenue) }\end{array}$ & $\begin{array}{l}\text { Time to prepare } \\
\text { and pay taxes } \\
\text { (hours) }\end{array}$ & $\begin{array}{l}\text { GINI index } \\
\text { (World Bank } \\
\text { estimate) }\end{array}$ & $\begin{array}{l}\text { Total tax and } \\
\text { contribution rate } \\
\text { (\% of profit) }\end{array}$ \\
\hline Austria & 27.61 & 47.01 & 0.00 & 154.13 & 30.27 & 51.87 \\
\hline Belgium & 35.84 & 58.35 & -141.53 & 28.43 & 57.73 & \\
\hline Bulgaria & 15.56 & 25.59 & 0.41 & 508.73 & 35.47 & 30.73 \\
\hline Croatia & 7.87 & 14.14 & 1.48 & 202.53 & 32.14 & 20.55 \\
\hline Cyprus & 24.99 & 38.10 & 0.63 & 139.75 & 32.62 & 22.17 \\
\hline The Czech Republic & 15.98 & 35.63 & 0.95 & 412.47 & 26.42 & 46.57 \\
\hline Denmark & 40.81 & 48.98 & -133.27 & 26.70 & 26.73 & \\
\hline Estonia & 20.36 & 35.93 & 0.08 & 73.13 & 33.25 & 50.57 \\
\hline Finland & 17.87 & 32.35 & 0.00 & 159.53 & 27.56 & 41.95 \\
\hline France & 25.07 & 47.58 & -0.01 & 134.87 & 32.09 & 66.67 \\
\hline Germany & 15.97 & 40.58 & -209.93 & 30.85 & 47.88 & \\
\hline Greece & 18.97 & 35.57 & 0.01 & 216.07 & 34.64 & 48.87 \\
\hline Hungary & 18.68 & 33.22 & 0.66 & 296.67 & 29.79 & 49.78 \\
\hline Ireland & 38.66 & 51.53 & -77.83 & 32.62 & 25.72 & \\
\hline Italy & 32.39 & 53.81 & -283.20 & 34.40 & 65.87 & \\
\hline Latvia & 10.92 & 20.59 & 0.36 & 219.20 & 36.03 & 36.32 \\
\hline Lithuania & 20.72 & 36.88 & 0.76 & 156.42 & 35.50 & 44.25 \\
\hline Luxembourg & 28.81 & 46.96 & -57.00 & 31.61 & 20.29 & \\
\hline Malta & 30.40 & 45.14 & 1.40 & 139.00 & 29.11 & 42.54 \\
\hline Norway & 28.55 & 52.26 & 0.20 & 84.60 & 27.22 & 39.85 \\
\hline Poland & 12.98 & 26.05 & 0,56 & 334.67 & 33.88 & 41.40 \\
\hline Romania & 18.62 & 33.35 & 0.86 & 189.67 & 36.58 & 42.65 \\
\hline Slovak Republic & 17.17 & 36.23 & 0.20 & 241.47 & 26.73 & 49.03 \\
\hline Slovenia & 12.62 & 25.05 & 1.07 & 234.27 & 24.95 & 33.62 \\
\hline Spain & 39.20 & 47.18 & -198.57 & 34.54 & 52.06 & \\
\hline Sweden & 14.36 & 17.62 & -122.00 & 27.42 & 51.51 & \\
\hline Ukraine & 12.90 & 26.28 & 3.58 & 804.60 & 26.50 & 52.64 \\
\hline The United Kingdom & 35.84 & 48.71 & -104.27 & 34.11 & 33.51 & \\
\hline
\end{tabular}

Source: compiled by authors based on World Bank data

Taxes on income, profit and capital gains are deducted from the actual or projected net income of individuals, from the profits of corporations and enterprises, as well as from capital gains. Taxes on income, profits and capital gains in \% of revenue are the highest in Denmark $(40.81 \%)$ and the lowest are in Croatia (7.87\%). In Ukraine this indicator is at the level of $12,90 \%$. Taxes on income, profits and capital gains in $\%$ of total taxes are the highest in $58.35 \%$, the lowest are in Croatia $14.14 \%$. In Ukraine this indicator is at the level of $26.28 \%$. GINI index (World Bank estimate) is the highest in Romania (36.58); the lowest one is in Slovenia (24.95); in Ukraine this indicator is at the level of 26.50.

Next, it was analyzed the profit tax in the EU and Ukraine. This is the amount of business income taxes paid.

In Table 3, it is shown that profit tax decreased in many countries in 2019 compared to 2005. A slight increase in profit tax is observed in Belgium, Germany, Greece, Hungary, Ireland, Latvia, Lithuania, and the Slovak Republic. In Ukraine, profit tax in\% of commercial profits decreased from 12.3 to $10.2 \%$, which is a positive trend.
Enterprise tax payments are the total amount of taxes paid by businesses, including the submission of electronic materials. The tax is considered paid once a year, even if it is more frequent.

Tax payments number, according to Table 4, decreased by 2-3 times in 2019 compared to 2005 in the countries of Bulgaria, Croatia, the Czech Republic, Finland, France, Greece, Latvia, Poland, Romania, the Slovak Republic, Slovenia. This decrease is considered a positive trend. In Ukraine, tax payments number decreased from 147 in 2005 to 5 in 2019. This is a very significant decrease.

Tax preparation and payment time is the time in hours per year for which you need to prepare, file and pay three main types of taxes: corporate income tax, value added tax or sales tax, and labor taxes.

A very significant decrease in time to prepare and pay taxes is observed in Ukraine more than five times, from 2085 hours in 2005 to 327 hours in 2019. This is a positive trend. The surveyed EU countries also show a decrease in this indicator. 
Vol. 6, No. 2, 2020

Baltic Journal of Economic Studies

Table 3

Profit tax, \% of commercial profits

\begin{tabular}{|c|c|c|c|c|c|c|c|c|}
\hline Country Name & 2005 & 2014 & 2015 & 2016 & 2017 & 2018 & 2019 & $\begin{array}{c}2019 \text { to } \\
2005 \text { ratio }\end{array}$ \\
\hline Austria & 21.2 & 16.8 & 16.8 & 16.9 & 17 & 17.1 & 17.1 & 80.66 \\
\hline Belgium & 9.8 & 8.3 & 8.4 & 9.1 & 10.3 & 10.9 & 10.3 & 105.10 \\
\hline Bulgaria & 7 & 5 & 5 & 5 & 5 & 4.9 & 4.9 & 70.00 \\
\hline Croatia & 0 & 0 & 0 & 0 & 0 & 0 & 0 & - \\
\hline Cyprus &.. & 9.5 & 9.3 & 9.6 & 8.1 & 8.1 & 8.3 & - \\
\hline The Czech Republic & 7.2 & 5.6 & 5.6 & 5.1 & 5.1 & 5.2 & 5.2 & 72.22 \\
\hline Denmark & 27.9 & 19.6 & 18.1 & 18.4 & 17.1 & 17.1 & 17.1 & 61.29 \\
\hline Estonia & 11.2 & 8.2 & 8.2 & 7.8 & 7.8 & 7.8 & 7.7 & 68.75 \\
\hline Finland & 19.1 & 14.6 & 11.8 & 11.7 & 11.7 & 11.9 & 12.1 & 63.35 \\
\hline France & 6.8 & 5.4 & -0.2 & 0.2 & 1 & 0.3 & 0.2 & 2.94 \\
\hline Germany & 21.4 & 23.3 & 23.2 & 23.2 & 23.2 & 23.2 & 23.2 & 108.41 \\
\hline Greece & 21.5 & 19 & 19.7 & 22.4 & 23 & 23 & 23 & 106.98 \\
\hline Hungary & 5.9 & 11.8 & 11.8 & 9.9 & 9.9 & 9.1 & 9.4 & 159.32 \\
\hline Ireland & 11.9 & 12.4 & 12.4 & 12.4 & 12.4 & 12.4 & 12.4 & 104.20 \\
\hline Italy & 30.6 & 19.9 & 19.5 & 17 & 23.3 & 16.8 & 14.6 & 47.71 \\
\hline Latvia & 6.8 & 4.9 & 6.3 & 6.3 & 6.3 & 6.4 & 7.8 & 114.71 \\
\hline Lithuania & 5.7 & 5.9 & 5.9 & 5.9 & 5.9 & 5.9 & 5.9 & 103.51 \\
\hline Luxembourg &.. & 4.6 & 4.6 & 4.6 & 4.2 & 4.2 & 4.2 & - \\
\hline Malta &.. & 30.2 & 30.2 & 32.4 & 32.3 & 32.3 & 32.3 & - \\
\hline Norway & 25.2 & 24.5 & 23.6 & 23.6 & 21.8 & 20.8 & 20 & 79.37 \\
\hline Poland & 14.8 & 14.5 & 14.5 & 14.5 & 14.5 & 14.5 & 14.5 & 97.97 \\
\hline Romania & 17.2 & 10.7 & 10.9 & 12.3 & 12.3 & 12.3 & 15.6 & 90.70 \\
\hline The Slovak Republic & 8 & 8.4 & 9.4 & 9.5 & 9.5 & 9.1 & 9.1 & 113.75 \\
\hline Slovenia & 14.3 & 12.7 & 12.7 & 12.7 & 12.7 & 12.7 & 12.7 & 88.81 \\
\hline Spain & 23.4 & 21.7 & 13.4 & 12.5 & 10.6 & 10.6 & 10.6 & 45.30 \\
\hline Sweden & 16.6 & 13.1 & 13.1 & 13.1 & 13.1 & 13.1 & 13.1 & 78.92 \\
\hline Ukraine & 12.3 & 9.5 & 9 & 8.7 & 11.9 & 11 & 10.2 & 82.93 \\
\hline The United Kingdom & 21.8 & 20.6 & 19.2 & 18.3 & 18.1 & 17.3 & 16.6 & 76.15 \\
\hline
\end{tabular}

Source: compiled by authors based on World Bank data

Table 4

Tax payments, number

\begin{tabular}{|l|c|c|c|c|c|c|c|c|c|}
\hline \multicolumn{1}{|c|}{ Country Name } & 2005 & 2013 & 2014 & 2015 & 2016 & 2017 & 2018 & 2019 & $\begin{array}{c}2019 \text { to } \\
2005 \text { ratio }\end{array}$ \\
\hline Austria & 12 & 12 & 12 & 12 & 12 & 12 & 12 & 12 & 100.00 \\
\hline Belgium & 11 & 11 & 11 & 11 & 11 & 11 & 11 & 11 & 100.00 \\
\hline Bulgaria & 29 & 14 & 14 & 14 & 14 & 14 & 14 & 14 & 48.28 \\
\hline Croatia & 40 & 12 & 12 & 12 & 13 & 13 & 12 & 12 & 30.00 \\
\hline Cyprus &.. & 31 & 30 & 28 & 28 & 28 & 27 & 16 & - \\
\hline The Czech Republic & 27 & 8 & 8 & 8 & 8 & 8 & 8 & 8 & 29.63 \\
\hline Denmark & 10 & 10 & 10 & 10 & 10 & 10 & 10 & 10 & 100.00 \\
\hline Estonia & 7 & 8 & 8 & 8 & 8 & 8 & 8 & 8 & 114.29 \\
\hline Finland & 20 & 8 & 8 & 8 & 8 & 8 & 8 & 8 & 40.00 \\
\hline France & 21 & 9 & 9 & 9 & 9 & 9 & 9 & 9 & 42.86 \\
\hline Germany & 12 & 9 & 9 & 9 & 9 & 9 & 9 & 9 & 75.00 \\
\hline Greece & 19 & 8 & 8 & 8 & 8 & 8 & 8 & 8 & 42.11 \\
\hline Hungary & 13 & 12 & 11 & 11 & 11 & 11 & 11 & 11 & 84.62 \\
\hline Ireland & 9 & 9 & 9 & 9 & 9 & 9 & 9 & 9 & 100.00 \\
\hline Italy & 14 & 13 & 13 & 14 & 14 & 14 & 14 & 14 & 100.00 \\
\hline Latvia & 29 & 7 & 7 & 7 & 7 & 7 & 7 & 7 & 24.14 \\
\hline Lithuania & 11 & 11 & 11 & 11 & 11 & 11 & 10 & 10 & 90.91 \\
\hline Luxembourg &. & 23 & 23 & 23 & 23 & 23 & 23 & 23 & - \\
\hline Malta &.. & 7 & 7 & 7 & 8 & 8 & 8 & 8 & - \\
\hline
\end{tabular}


(End of Table 4)

\begin{tabular}{|l|c|c|c|c|c|c|c|c|c|}
\hline \multicolumn{1}{|c|}{ Country Name } & 2005 & 2013 & 2014 & 2015 & 2016 & 2017 & 2018 & 2019 & $\begin{array}{c}2019 \text { to } \\
2005 \text { ratio }\end{array}$ \\
\hline Norway & 4 & 4 & 4 & 4 & 4 & 4 & 5 & 5 & 125.00 \\
\hline Poland & 41 & 19 & 19 & 7 & 7 & 7 & 7 & 7 & 17.07 \\
\hline Romania & 108 & 39 & 14 & 14 & 14 & 14 & 14 & 14 & 12.96 \\
\hline The Slovak Republic & 32 & 22 & 22 & 11 & 8 & 8 & 8 & 8 & 25.00 \\
\hline Slovenia & 22 & 10 & 10 & 10 & 10 & 10 & 10 & 10 & 45.45 \\
\hline Spain & 8 & 9 & 9 & 9 & 8 & 9 & 9 & 9 & 112.50 \\
\hline Sweden & 6 & 6 & 6 & 6 & 6 & 6 & 6 & 6 & 100.00 \\
\hline Ukraine & 147 & 28 & 5 & 5 & 5 & 5 & 5 & 5 & 3.40 \\
\hline The United Kingdom & 8 & 8 & 8 & 8 & 8 & 8 & 8 & 9 & 112.50 \\
\hline
\end{tabular}

Source: compiled by authors based on World Bank data

Table 5

Time to prepare and pay taxes, hours

\begin{tabular}{|c|c|c|c|c|c|c|c|c|c|c|}
\hline Country Name & 2005 & 2012 & 2013 & 2014 & 2015 & 2016 & 2017 & 2018 & 2019 & $\begin{array}{c}2019 \text { to } \\
2005 \text { ratio }\end{array}$ \\
\hline Austria & 170 & 170 & 166 & 131 & 131 & 131 & 131 & 131 & 131 & 77.06 \\
\hline Belgium & 156 & 131 & 135 & 135 & 136 & 136 & 136 & 136 & 136 & 87.18 \\
\hline Bulgaria & 598 & 436 & 436 & 436 & 453 & 453 & 453 & 453 & 441 & 73.75 \\
\hline Croatia & 232 & 196 & 196 & 208 & 206 & 206 & 206 & 206 & 206 & 88.79 \\
\hline Cyprus &.. & 146 & 146 & 146 & 145 & 127 & 127 & 122 & 119 & - \\
\hline The Czech Republic & 866 & 230 & 230 & 230 & 222 & 222 & 236 & 230 & 230 & 26.56 \\
\hline Denmark & 135 & 130 & 132 & 132 & 132 & 132 & 132 & 132 & 132 & 97.78 \\
\hline Estonia & 81 & 81 & 81 & 81 & 81 & 56 & 50 & 50 & 50 & 61.73 \\
\hline Finland & 269 & 93 & 93 & 93 & 93 & 93 & 93 & 90 & 90 & 33.46 \\
\hline France & 132 & 132 & 137 & 137 & 137 & 139 & 139 & 139 & 139 & 105.30 \\
\hline Germany & 196 & 207 & 218 & 218 & 218 & 218 & 218 & 218 & 218 & 111.22 \\
\hline Greece & 264 & 202 & 193 & 193 & 193 & 193 & 193 & 193 & 193 & 73.11 \\
\hline Hungary & 340 & 277 & 277 & 277 & 277 & 277 & 277 & 277 & 277 & 81.47 \\
\hline Ireland & 75 & 79 & 79 & 79 & 81 & 81 & 81 & 81 & 81,5 & 108.67 \\
\hline Italy & 340 & 269 & 269 & 269 & 269 & 240 & 238 & 238 & 238 & 70.00 \\
\hline Latvia & 280 & 224 & 224 & 193 & 193 & 168 & 168 & 168 & 168 & 60.18 \\
\hline Lithuania & 166 & 175 & 175 & 171 & 171 & 171 & 109 & 99 & 95 & 57.23 \\
\hline Luxembourg &.. & 59 & 55 & 55 & 55 & 55 & 55 & 55 & 55 & - \\
\hline Malta & .. & 139 & 139 & 139 & 139 & 139 & 139 & 139 & 139 & - \\
\hline Norway & 87 & 87 & 83 & 83 & 83 & 83 & 83 & 79 & 79 & 90.80 \\
\hline Poland & 420 & 286 & 286 & 286 & 269 & 269 & 258 & 334 & 334 & 79.52 \\
\hline Romania & 192 & 218 & 202 & 161 & 161 & 161 & 163 & 163 & 163 & 84.90 \\
\hline The Slovak Republic & 325 & 207 & 207 & 207 & 188 & 192 & 192 & 192 & 192 & 59.08 \\
\hline Slovenia & 248 & 233 & 233 & 233 & 233 & 233 & 233 & 233 & 233 & 93.95 \\
\hline Spain & 298 & 167 & 167 & 167 & 158 & 152 & 152 & 147 & 143 & 47.99 \\
\hline Sweden & 122 & 122 & 122 & 122 & 122 & 122 & 122 & 122 & 122 & 100.00 \\
\hline Ukraine & 2085 & 488 & 386 & 346 & 346 & 355 & 327 & 327 & 327 & 15.71 \\
\hline The United Kingdom & 100 & 105 & 105 & 105 & 105 & 105 & 105 & 105 & 114 & 114.00 \\
\hline
\end{tabular}

Source: compiled by authors based on World Bank data

The GINI index measures the extent to which the distribution of income among individuals or households within the economy deviatesfrom a uniform distribution. Thus, the GINI index of 0 represents perfect equality, while the index of 100 indicates perfect inequality. According to the GINI index (Figure 1), Ukraine ranks the 26th in the 2005-2019 average compared to the EU countries. According to the UN, more than $60 \%$ of the population lives below the poverty line in Ukraine, but according to the World Bank, the figure is $25 \%$ ).
One of the areas that needs to be improved is tax policy, since tax revenues form a large revenue part of the state budget.

The total tax rate measures the amount of taxes and mandatory contributions paid by businesses after accounting for allowable deductions as a proportion of commercial income.

Let us compare in more detail three countries of approximately the same area: Ukraine (579290 sq. Km), Spain (499564 sq. Km), and France (547557 sq. Km). 
Vol. 6, No. 2, 2020

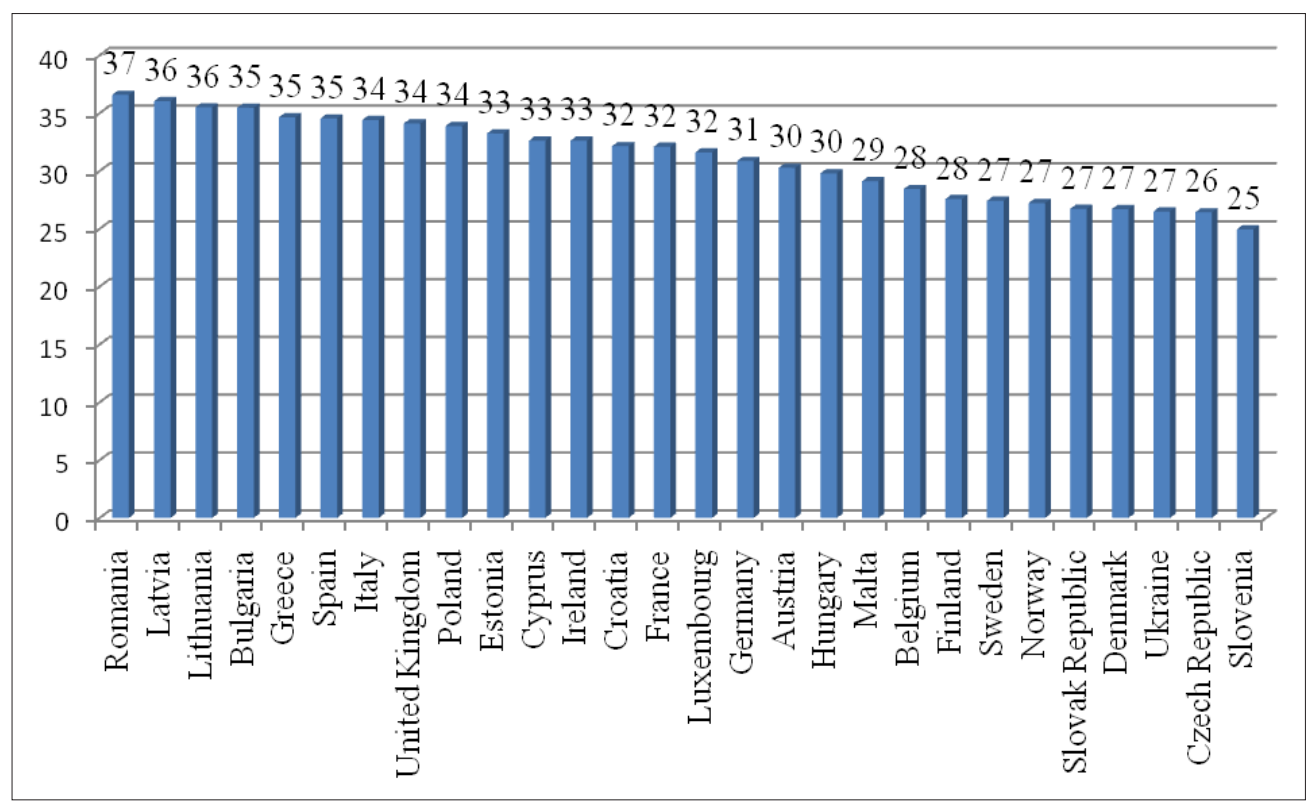

Figure 1. Gini index of the EU countries and Ukraine

Source: compiled by authors based on World Bank data

Table 6

Total tax and contribution rate, $\%$ of profit

\begin{tabular}{|c|c|c|c|c|c|c|c|c|c|}
\hline Country Name & 2005 & 2013 & 2014 & 2015 & 2016 & 2017 & 2018 & 2019 & $\begin{array}{c}2019 \text { to } \\
2005 \text { ratio }\end{array}$ \\
\hline Austria & 57.2 & 51.9 & 51.7 & 51.7 & 51.6 & 51.8 & 51.5 & 51.4 & 89.86 \\
\hline Belgium & 60.1 & 58 & 58.4 & 58.4 & 58.7 & 57.1 & 57.7 & 55.4 & 92.18 \\
\hline Bulgaria & 45.2 & 27 & 27 & 27 & 27 & 27.1 & 27.7 & 28.3 & 62.61 \\
\hline Croatia & 20.8 & 19.3 & 18.4 & 20 & 20.9 & 20.6 & 20.5 & 20.5 & 98.56 \\
\hline Cyprus &.. & 21.9 & 22.5 & 24 & 24.2 & 22.7 & 22.2 & 22.4 & - \\
\hline The Czech Republic & 48.7 & 45.6 & 46.5 & 46.5 & 46.1 & 46.1 & 46.1 & 46.1 & 94.66 \\
\hline Denmark & 32.6 & 25.6 & 25.4 & 23.9 & 24.4 & 23.8 & 23.8 & 23.8 & 73.01 \\
\hline Estonia & 50.4 & 49.6 & 49.2 & 49.2 & 48.5 & 48.5 & 48.5 & 47.8 & 94.84 \\
\hline Finland & 49.5 & 39.9 & 40.1 & 37.9 & 38.1 & 38.4 & 37.3 & 36.6 & 73.94 \\
\hline France & 68.3 & 69.8 & 71.3 & 64.9 & 64.1 & 62.6 & 60.4 & 60.7 & 88.87 \\
\hline Germany & 47.7 & 49.1 & 48.8 & 48.8 & 48.9 & 48.9 & 49 & 48.8 & 102.31 \\
\hline Greece & 54 & 44 & 50.7 & 49.6 & 50.7 & 51.7 & 51.9 & 51.9 & 96.11 \\
\hline Hungary & 53.6 & 49.2 & 47.9 & 48.2 & 46.3 & 46.4 & 40.3 & 37.9 & 70.71 \\
\hline Ireland & 25.4 & 25.9 & 26 & 26 & 26 & 26 & 26 & 26.1 & 102.76 \\
\hline Italy & 76.7 & 65.6 & 65.2 & 64.8 & 62 & 48 & 53.1 & 59.1 & 77.05 \\
\hline Latvia & 36.2 & 35 & 35 & 35.9 & 35.9 & 35.9 & 36 & 38.1 & 105.25 \\
\hline Lithuania & 51.2 & 42.9 & 42.4 & 42.6 & 42.6 & 42.7 & 42.6 & 42.6 & 83.20 \\
\hline Luxembourg &.. & 20.4 & 20.6 & 20.6 & 20.8 & 20.5 & 20.5 & 20.4 & - \\
\hline Malta &.. & 41.4 & 41.5 & 41.5 & 43.8 & 43.9 & 44 & 44 & - \\
\hline Norway & 41.1 & 40.7 & 40.4 & 39.5 & 39.5 & 37.7 & 37 & 36.2 & 88.08 \\
\hline Poland & 43.2 & 40.1 & 40.1 & 40.3 & 40.4 & 40.5 & 40.7 & 40.8 & 94.44 \\
\hline Romania & 55.8 & 43.2 & 43.2 & 42 & 40 & 40 & 40 & 20 & 35.84 \\
\hline The Slovak Republic & 50 & 48.7 & 49.4 & 50.4 & 50.1 & 50.1 & 49.7 & 49.7 & 99.40 \\
\hline Slovenia & 39.2 & 31.4 & 31 & 31 & 31 & 31 & 31 & 31 & 79.08 \\
\hline Spain & 60.4 & 56.9 & 57.9 & 49.8 & 48.7 & 46.9 & 47 & 47 & 77.81 \\
\hline Sweden & 54.1 & 52.1 & 49.1 & 49.1 & 49.1 & 49.1 & 49.1 & 49.1 & 90.76 \\
\hline Ukraine & 57.3 & 54.4 & 52.7 & 52.2 & 52.3 & 37.8 & 41.7 & 45.2 & 78.88 \\
\hline The United Kingdom & 34.7 & 34.7 & 33.5 & 32 & 30.9 & 30.7 & 30 & 30.6 & 88.18 \\
\hline
\end{tabular}

Source: compiled by authors based on World Bank data 
Table 7

General indicators of the economies development of the studied countries on average for 2001-2019

\begin{tabular}{|l|c|c|c|}
\hline \multicolumn{1}{|c|}{ Indicator } & Spain & France & Ukraine \\
\hline Population, total & 46723749 & 66987244 & 44622516 \\
\hline Land area (sq. km) & 499564 & 547557 & 579290 \\
\hline Foreign direct investment, net inflows (\% of GDP) & 3.15 & 2.15 & 1.89 \\
\hline GDP growth (annual \%) & 2.35 & 1.72 & 15.41 \\
\hline Inflation, GDP deflator (annual \%) & 1.09 & 0.79 & 9.78 \\
\hline Interest payments (\% of expense) & 12.10 & 3.63 & 99.02 \\
\hline Trade (\% of GDP) & 67.52 & 66.45 & 2.89 \\
\hline Net acquisition of financial assets (\% of GDP) & 2.59 & 4.62 & 53.81 \\
\hline Imports of goods and services (\% of GDP) & 32.40 & 32.11 & 45.21 \\
\hline Exports of goods and services (\% of GDP) & 35.12 & 31.34 & 994.08 \\
\hline Researchers in R\&D (per million people) & 2873.41 & 4441.07 & \\
\hline
\end{tabular}

Source: compiled by authors based on World Bank data

Therefore, Ukraine needs further tax reform, which should emphasize:

1) simplification of tax legislation, elimination of contradictions and shortcomings in it;

2) simplification and automatization of $\operatorname{tax}$ administration, improving the system of risk-oriented tax control (including the introduction of indirect tax control methods), improving relations between tax authorities and taxpayers, taking into account the experience of the EU countries.

With the shift in socio-economic development, the shading of economic relations and the further resolution of fiscal problems in Ukraine, tax policy of the EU and its Member States should increasingly be taken into account.

Therefore, considering the tax system of the European countries, it can be noted that the tax system of each country has its own features that can and should be taken into account when reforming the tax system of Ukraine. It is advisable to use the experience of other countries. Research on the performance of the tax system in dynamics should be used to create an effective tax system to prevent mistakes and miscalculations that adversely affect the economic development of states.

\section{Results}

Next, there was studied the dependence of foreign direct investment, net inflows (\% of GDP) (Y) on profit $\operatorname{tax}\left(\%\right.$ of commercial profits) $\left(\mathrm{X}_{1}\right)$, tax revenue (\% of $\mathrm{GDP})\left(\mathrm{X}_{2}\right)$; taxes on income, profits and capital gains (\% of revenue) $\left(\mathrm{X}_{3}\right)$; time to prepare and pay taxes (hours) $\left(\mathrm{X}_{4}\right)$ and total tax rate (\% of commercial profits) $\left(\mathrm{X}_{5}\right)$. In order to test the hypotheses, data from three countries for 2001-2019 were obtained by the sampling method.

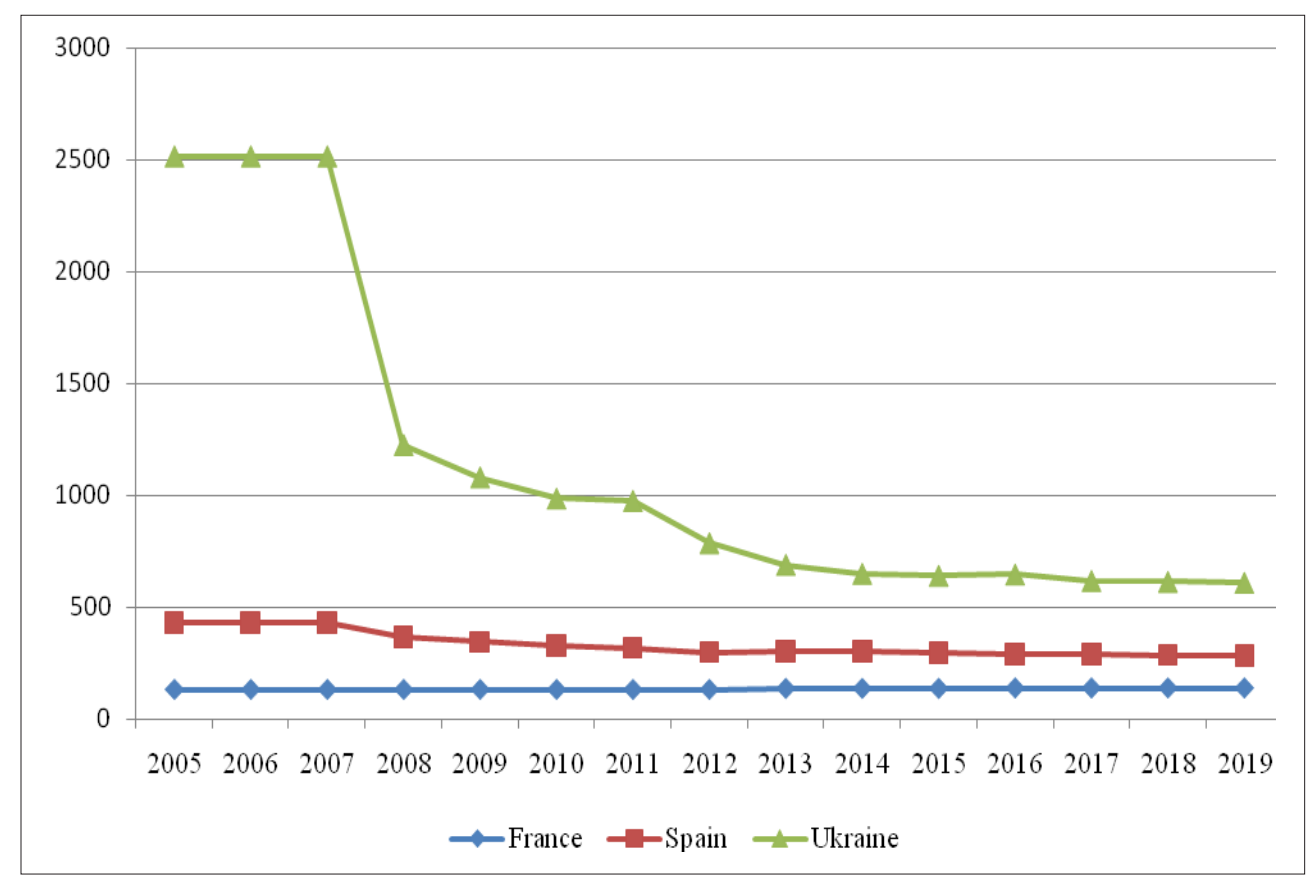

Figure 2 Dynamics of change "time to prepare and pay taxes" indicator in three studied countries, hours 
Several equations can be used to describe the regression, the most important of which is the Fisher's criterion. The Fisher's test is used for verification of different hypotheses. If the hypothesis about the significance of the chosen regression model is tested, its empirical value is calculated:

$$
\hat{F}=\frac{\frac{1}{n} \cdot\left(\sum_{i=1}^{n}\left(Y_{i}-\bar{Y}\right)^{2}\right)}{\frac{1}{n-m-1} \cdot\left(\sum_{i=1}^{n}\left(Y_{i}-\hat{Y}_{i}\right)^{2}\right)},
$$

where $m$ is the number of factor features of the model. The multiple regression model should include factors that are strongly correlated with the resultant variable and not strongly correlated with each other. Multicollinearity is an undesirable phenomenon. For the selection of factors to be included in the regression model, all elements of the matrix of paired correlation coefficients are calculated.

The matrix of double correlation coefficients is symmetric: the values of the correlation coefficients above and below the principal diagonal (ie $r_{12}=r_{21}$ etc.). The values of the elements on the main diagonal of the matrix are always equal to one. The results of the calculations of the coefficients are given in Table 8 .

The analysis of the matrix shows that there is a strong internal correlation between the factor variables $X_{1} \mathrm{i}$ $\mathrm{X}_{2}$ and the correlation coefficient is 0.96268 . Of these, the factor variable $X_{2}$ (correlation coefficient 0.97342 ) has a slightly stronger effect on the resultant indicator. Therefore, we exclude the factor variable $X_{1}$ from further consideration. The matrix of paired correlation coefficients for the remaining variables is as follows (Table 9).

There are no factor variables in this matrix, which are closely related with a correlation coefficient of more than 0.8 .
Thus, to further investigate the impact on Foreign direct investment, net inflows $(Y)$, it should be left four factor variables: Tax revenue (\% of GDP) $\left(X_{2}\right)$; Taxes on income, profits and capital gains (\% of revenue) $\left(X_{3}\right)$; Time to prepare and pay taxes (hours) $\left(X_{4}\right)$, and Total tax rate (\% of commercial profits) $\left(X_{5}\right)$.

The multivariate correlation analysis evaluates the link strength of the investigated variables and the multiple regression model to describe the factor link it is selected a multivariate statistical model. It is necessary to build a linear regression model with $m$ independent (factor) variables:

$\hat{\mathrm{Y}}_{\mathrm{t}}=\mathrm{a}_{0} \mathrm{X}_{\mathrm{i} 0}+\mathrm{a}_{1} \mathrm{X}_{\mathrm{i} 1}+\mathrm{a}_{2} \mathrm{X}_{\mathrm{i} 2}+\mathrm{a}_{\mathrm{m}} \mathrm{X}_{\mathrm{im}}+\varepsilon_{\mathrm{i}}$,

where $X_{i j}$ - are the factor variables observed on the $\mathrm{i}^{\text {th }}$ object;

$i$ - number in the order of the object under study, $i=1,2, \ldots, n$;

$\varepsilon_{i}-$ a random error that has a mathematical reading of 0 and a variance $\sigma^{2}$;

$X_{i 0}$ is a dummy variable equal to 1 in all observations.

The parameters $a_{i j}$ to be evaluated are unknown in this model.

On the basis of the previous paired correlationregression analysis, it is established the dependence of foreign direct investment, net inflows $(Y)$ on four indicators: Tax revenue (\% of GDP) $\left(X_{2}\right)$; Taxes on income, profits and capital gains (\% of revenue) $\left(X_{3}\right)$; Time to prepare and pay taxes (hours) $\left(X_{4}\right)$ та Total tax rate (\% of commercial profits) $\left(X_{5}\right)$. All factor variables have not multi-linear relationships. The multivariate regression model is assumed to be linear:

$$
\hat{Y}_{t}=a_{0} X_{0}+a_{1} X_{1}+a_{2} X_{2}+a_{3} X_{3}+a_{4} X_{4}+a_{5} X_{5} \text {, }
$$

To estimate the parameters, we use data previously considered for three countries without a factor $X_{1}$. The output to estimate the regression model parameters is supplemented by a dummy variable $X_{0}$. It is found the vector of the regression model parameters

Table 8

The original matrix of paired correlation coefficients

\begin{tabular}{|c|c|c|c|c|c|c|}
\hline Variables & $Y$ & $X_{1}$ & $X_{2}$ & $X_{3}$ & $X_{4}$ & $X_{5}$ \\
\hline$Y$ & 1.00000 & & & & & \\
\hline$X_{1}$ & $\mathbf{0 . 9 7 1 8 5}$ & 1.00000 & & & & \\
\hline$X_{2}$ & $\mathbf{0 . 9 7 3 4 2}$ & $\mathbf{0 . 9 6 2 6 8}$ & 1.00000 & & & \\
\hline$X_{3}$ & 0.59370 & 0.40481 & 0.56789 & 1.00000 & & \\
\hline$X_{4}$ & 0.72654 & 0.74487 & 0.77043 & 0.06234 & 1.00000 & \\
\hline$X_{5}$ & 0.84128 & 0.86542 & 0.66342 & 0.78329 & 0.70376 & 1.00000 \\
\hline
\end{tabular}

Table 9

The reduced matrix of paired correlation coefficients

\begin{tabular}{|c|c|c|c|c|c|}
\hline Variables & $Y$ & $X_{2}$ & $X_{3}$ & $X_{4}$ & $X_{5}$ \\
\hline$Y$ & 1.00000 & & & & \\
\hline$X_{1}$ & 0.97342 & 1.00000 & & & \\
\hline$X_{2}$ & 0.59370 & 0.56789 & 1.00000 & & 1.00000 \\
\hline$X_{3}$ & 0.72654 & 0.77043 & 0.06234 & 0.70376 & 1.00000 \\
\hline$X_{4}$ & 0.84128 & 0.66342 & 0.78329 & & \\
\hline$X_{5}$ & & & & & \\
\hline
\end{tabular}




$$
a=\left(X^{T} X\right)^{-1} \cdot X^{T} Y=\mid \begin{array}{r|r}
233,664552 & 0,004414 \\
0,004414 & 0,00001 \\
-165,980835 & -0,002651 \\
-88,326984 & -0,00169 \\
61,167152 & 0,000729
\end{array}
$$

It was written the regression model using the numerical values of the regression parameters

$$
\begin{aligned}
& \hat{Y}_{\mathrm{t}}=-2,341+4,1598 \mathrm{X}_{\mathrm{i} 2}-1,9615 \mathrm{X}_{\mathrm{i3}}-1,7167 \mathrm{X}_{\mathrm{i4}}+ \\
& +1,3401 \mathrm{X}_{\mathrm{i} 5} \\
& \text { and it is defined the area of factor variables change } \\
& 4,56 \leq X_{i 2} \leq 2,099 \\
& 0,93074 \leq X_{i 3} \leq 1,69878 \\
& 2,29698 \leq X_{i 4} \leq 3,54427 \\
& 2,35746 \leq X_{i 5} \leq 5,41386
\end{aligned}
$$

Positive signs of model parameters indicate that an increase in the relevant factors leads to an increase in the performance indicator, and negative signs of the model parameters indicate that an increase in the corresponding factors leads to a decrease in the performance indicator.

Thus, in the research above, increases in tax revenue (\% of GDP) $\left(X_{i 2}\right)$ and total tax rate (\% of commercial profits) $\left(X_{i 5}\right)$ cause an increase in the resultant variable, whereas growth in taxes on income, profits and capital gains $\left(\mathrm{X}_{\mathrm{i3}}\right)$ and time to prepare and pay taxes (hours) $\left(X_{i 4}\right)$ cause a decrease in the output variable: Foreign direct investment, net inflows (\% of GDP). The nature of the impact on FDI of the last two variables is contrary to economic content. However, this is due to the fact that, within the linear regression model, we have roughly replaced the nonlinear relationship between Taxes on income, profits and capital gains $\left(X_{\mathrm{i} 3}\right)$ and Time to prepare and pay taxes (hours) $\left(X_{i 4}\right)$ with the magnitude of FDI, which is one of the reasons for the appearance of a minus sign in the regression parameters for these variables.

The magnitude of each parameter in the model indicates how much the value of the resulting variable will change by increasing or decreasing the relevant factor by one unit.

Thus, in a study with a $1 \%$ increase in the factor variable $X_{i 2}$, the resultant variable (Foreign direct investment, net inflows) will increase by $4.1598 \%$, and with the $1 \%$ increase in the factor variable $X_{i 5}$ by $1.3401 \%$. An increase in the other two factor variables leads to a decrease in the resultant variable.

The degree of influence of factor variables on the outcome variable can be detected in two ways: 1) by analyzing the parameters of the regression model; 2) by analyzing the private correlation coefficients. In this paper the first method was used, which was the least time consuming and simple.

The estimation of the factors influence degree by analyzing the parameters (coefficients) of the regression model can be performed in two ways:

$\begin{array}{rr}\ldots & 61,167152 \\ \ldots & 0,000729 \\ \ldots & -44,437166 \\ \ldots & -23,459449 \\ \ldots & 16,730803\end{array}|\bullet| \begin{array}{r}106890,0 \\ 160603392,0 \\ 159030,0 \\ 313010,1 \\ 463580,1\end{array}|=| \begin{array}{r}-2014,2994 \\ 4,1598 \\ -1961,5899 \\ -171,3482 \\ 1340,8085\end{array} \mid$

- using beta coefficients;

- using the coefficients of elasticity.

A direct comparison of regression coefficients in the multiple regression equation gives an idea of the factor influence degree traits on the outcome variable only when they are expressed in identical units and have approximately the same fluctuations. Normalized regression coefficients $\beta_{j}$ are used to make the regression coefficients comparable. The coefficient $\beta_{j}$ shows the magnitude of the change in the result factor in the values of the root mean square error when changing the factor sign $\mathrm{X}_{\mathrm{i}}$ by one standard error:

$$
\beta_{\mathrm{j}}=\mathrm{a}_{\mathrm{j}}\left(\sigma_{\mathrm{xi}} / \sigma_{\mathrm{y}}\right) \text {, }
$$

where $a_{j}$ is the regression coefficient at the $X_{j}$ factor, $j=1,2, \ldots, m$.

The $\beta_{j}$ coefficients that characterize the impact of Tax revenue $\left(\beta_{2}\right)$, Taxes on income, profits and capital gains $\left(\beta_{3}\right)$, Time to prepare and pay taxes $\left(\beta_{4}\right)$ and Total tax rate $\left(\beta_{5}\right)$ on Foreign direct investment, net inflows in the model are calculated:

$$
\begin{aligned}
& \hat{\mathrm{Y}}_{\mathrm{t}}=-2,341+4,1598 \mathrm{X}_{\mathrm{i} 2}-1,9615 \mathrm{X}_{\mathrm{i} 3}-1,7167 \mathrm{X}_{\mathrm{i} 4}+ \\
& +1,3401 \mathrm{X}_{\mathrm{i} 5}
\end{aligned}
$$

Mean square deviations of the variables:

$$
\begin{aligned}
& \sigma_{Y}=-2,447,1 ; \sigma_{X_{2}}=448,6 ; \sigma_{X_{3}}=0,2023531 ; \\
& \sigma_{X_{4}}=-0,360497 ; \sigma_{X_{5}}=0,7440662 .
\end{aligned}
$$

To calculate beta coefficients we use the formula $\beta_{j}=a_{j}\left(\frac{\sigma_{X_{i}}}{\sigma_{y}}\right)$. We obtain the following values:

$$
\begin{aligned}
& \beta_{2}=0,76242 \\
& \beta_{3}=0,16221 \\
& \beta_{4}=0,02524 \\
& \beta_{5}=0,407687
\end{aligned}
$$

From here it was seen that the most significant impact on Foreign direct investment, net inflows is made by Tax revenue $\beta_{2}=0,76242$, Total tax rate $\beta_{5}=0,407687$.

In doing so, Tax revenue affects Foreign direct investment, net inflows in 1.9 times $(0.76242$ / 0.407687) stronger than Total tax rate.

Also, temporary elasticity coefficients $E_{j}$ are used to estimate the degree of influence of factor traits, relative $\mathrm{X}_{\mathrm{j}}$.

$$
E_{j}=\frac{\partial \hat{\mathrm{Y}}}{\partial \mathrm{X}_{j}} \cdot \frac{\mathrm{X}_{j}}{\hat{\mathrm{Y}}} \text { or } E_{j} \approx a_{j} \cdot \frac{\bar{X}_{j}}{\bar{Y}},
$$

where $\frac{\partial \hat{\mathrm{Y}}}{\partial \mathrm{X}_{j}}$ is a derivative of a regression on a variable $X_{j}$.

The coefficient $\mathrm{E}_{\mathrm{j}}$ shows how many percent the result will change if the factor is changed by one percent when 
the values of other factors are fixed at any level. The coefficients of elasticity $E_{j}$ that characterize the impact of Tax revenue $\left(E_{2}\right)$, Taxes on income, profits and capital gains $\left(E_{3}\right)$, Time to prepare and pay taxes $\left(E_{4}\right)$ and Total tax rate $\left(E_{5}\right)$ on Foreign direct investment, net inflows in the model are calculated

$$
\begin{aligned}
& \hat{Y}_{t}=-20,341+4,1598 X_{i 2}-1,9615 X_{i 3}-1,7167 X_{i 4}+ \\
& +1,3401 X_{i 5}
\end{aligned}
$$

Under these conditions, the coefficients of elasticity are as follows:

$$
\begin{aligned}
& E_{2}=0,9768 \\
& E_{3}=0,5041 \\
& E_{4}=0,0857 \\
& E_{5}=0,9612
\end{aligned}
$$

Comparison of the coefficients shows that on average Tax revenue affects Foreign direct investment, net inflows with the same strength as Time to prepare and pay taxes $\left(E_{2}=0,9768 ; E_{5}=0,9612\right)$, but almost twice as much as Taxes on income, profits and capital gains $\left(E_{3}=0,5041\right)$.

This conclusion does not coincide with the conclusion obtained using beta coefficients. It is accepted that a more accurate conclusion is the use of beta coefficients. However, elasticity coefficients have a better economic interpretation. Thus, using a correlation-regression analysis, a regression equation is constructed that can be applied in calculating the projected value of foreign direct investment into the country.

\section{Conclusions}

Therefore, tax policy and its tasks within a systematic approach can be formulated as a concept of "economic development priority ", which implies in the conflict situations the search and implementation of those solutions that are optimal for most participants in economic relations. The concept of "economic development priority" is based on the laws of interaction between the part and the whole, and takes into account the concept and methods of forming optimal decisions in order to increase efficiency.

In the article it is examined the dependence of foreign direct investment, net inflows (\% of GDP) (Y) on profit tax (\% of commercial profits) (X1), tax revenue (\% of GDP) (X2); taxes on income, profits and capital gains (\% of revenue) (X3); time to prepare and pay taxes (hours) (X4) and total tax rate (\% of commercial profits) (X5). Thus, in a study with a $1 \%$ increase in the factor variable $X_{i 2}$, the foreign variable investment (net inflows) will increase by $4,1598 \%$, and with the $1 \%$ increase in the factor variable $X_{i 5}$ the foreign variable investment will increase by $1,3401 \%$. An increase in the other two factor variables leads to a decrease in the resultant variable.

The coefficients of elasticity that characterize the impact of tax revenue, Taxes on income, profits and capital gains, time to prepare and pay taxes, and time to prepare and pay taxes on foreign direct investment, net inflows in the model have been calculated. Comparison of ratios shows that on average tax revenue affects foreign direct investment, net inflows with the same strength as time to prepare and pay taxes $\left(E_{2}=0,9768 ; E_{5}=0,9612\right)$, but almost twice as much as taxes on income, profits and capital gains $\left(E_{3}=0,5041\right)$. Thus, using a correlationregression analysis, a regression equation is constructed that can be applied in calculating the projected value of foreign direct investment into the country.

\section{References:}

Adegbie, F., \& Faklie, S. (2011). Petroleum Profit Tax and Nigeria Economic Development. International Journal of Research in Computer Application \& Management, vol. 1(1), pp. 11-18. Retrieved from: http://eprints.covenantuniversity.edu.ng/1657/\#.XWd0R-gzaUk (accessed November 17, 2019).

European Commission (2019). Taxes in Europe (database). Retrieved from: http://ec.europa.eu/taxation_ customs/tedb/taxSearch.html (accessed January 20, 2020).

European Union (2019). Income taxes abroad. Retrieved from: https://europa.eu/youreurope/citizens/work/ taxes/income-taxesabroad/index_en.htm (accessed January 20, 2020).

Eurostat (n.d.). People at risk of poverty or social exclusion. Retrieved from: https://ec.europa.eu/eurostat/tgm/ refreshTableAction.do;jsessionid=sP6HwYN3Mg0gLIDEO1RdPEnRKtxDyKohd15p8a6f_5Y1L2UD9_a8!1987023697 tab $=$ table\&plugin $=1 \&$ pcode $=t 2020 \_50 \&$ language $=$ en $($ accessed January 28, 2020).

Filipenko, A. (2017). A Social and Solidarity Economy: The Ukrainian choice (1st ed.) (230 p.). Retrieved from: https://www. cambridgescholars.com/a-socialand-solidarity-economy (accessed December 19, 2019).

Glushchenko, J., \& Kozhalina, N. (2019). Development trends of local taxes in the system of local budgets in Ukraine. Public and Municipal Finance, vol. 8(1), pp. 104-111. doi: 10.21511/pmf.08(1).2019.09

Guerra, A., \& Harrington, B. (2018). Attitude-behaviour consistency in tax compliance: A cross-national comparison. Journal of Economic Behavior and Organization, vol. 156, pp. 184-205. doi: 10.1016/j. jebo.2018.10.013 Hrysenko, M., Pryiatelchuk, O., \& Shvorak, L. (2019). Modeling of state socio-economic systems in the countries of the European region. Problems and Perspectives in Management, vol. 17(3), pp. 452-463. doi: 10.21511/ ppm.17(3).2019.36

Khalatur, S., Radzevicius, G., Velychko, L., Fesenko, V., \& Kriuchko, L. (2019). Global deoffshorization and its impact on the national and regional economies of eastern european countries. Problems and Perspectives in Management, vol. 17(3), pp. 293-305. doi: 10.21511/ppm.17(3).2019.24 
Naidenko, O. (2019). Justification of tax regulation tools to support the poor. Economics of Development, vol. 18(3), pp. 45-57. doi: 10.21511/ed.18(3).2019.05

Olubukola Ranti Uwuigbe, Ayomide Omoyiola, Uwalomwa Uwuigbe, Nassar Lanre and Opeyemi Ajetunmobi (2019). Taxation, exchange rate and foreign direct investment in Nigeria. Banks and Bank Systems, vol. 14(3), pp. 76-85. doi: 10.21511/bbs.14(3).2019.07

Olufemi Adebayo Oladipo, Francis Iyoha, Adeniran Fakile, Abiola John Asaleye and Damilola Felix Eluyela (2019). Tax revenue and agricultural performance: evidence from Nigeria. Problems and Perspectives in Management, vol. 17(3), pp. 342-349. doi: 10.21511/ppm.17(3).2019.27

Official website of the State Statistics Committee. Retrieved from: www.ukrstat.gov.ua (accessed January 26, 2020).

Official website of the National Bank of Ukraine. Retrieved from: https://bank.gov.ua (accessed January 24, 2020). Perez-truglia, R., \& Troiano, U. (2018). Shaming tax delinquents. Journal of Public Economics, vol. 167, pp. 120-137. doi: $10.1016 /$ j. jpubeco.2018.09.008

The World Bank (2020a). Foreign direct investment, net inflows (\% of GDP). Retrieved from: https://data. worldbank.org/indicator/bx.klt.dinv.wd.gd.zs (accessed January 20, 2020).

The World Bank (2020b). World Development Indicators. Retrieved from: http://databank.worldbank.org/data/ reports.aspx? source=world-development-indicators (accessed January 11, 2020).

Tsina Derzhavy [Value of the State]. (n.d.). Retrieved from: http://cost.ua/budget/ revenue (accessed January 26, 2020).

Vasylieva, N. (2018). Ukrainian Agricultural Contribution to the World Food Security: Economic Problems and Prospects. Montenegrin Journal of Economics, vol. 14(4), pp. 215-224. doi: 10.14254/1800-5845/2018.14-4.15

Velychko, O., \& Velychko, L. (2017). Logistical modelling of managerial decisions in social and marketing business systems. Journal of International Studies, vol. 10(3), pp. 206-219. doi: 10.14254/2071-8330.2017/10-3/15 